\title{
Ainu Identity and Japan's Identity: The Struggle for Subjectivity
}

\author{
ALEXANDER BUKH
}

\begin{abstract}
This paper seeks to contribute to the academic debate on the contemporary identity of the Ainu. Ainu, the indigenous people of what today constitutes part of northern Japan, as well as the Russian Kurile Islands and parts of the island of Sakhalin, became the first subjects of modernizing Japan's expansion in the second half of the nineteenth century. In general, the Ainu's history, culture, and the struggle for recognition as indigenous people as well as against discrimination in Japan have been subjected to intense academic scrutiny in both English and Japanese. This article, however, aims to shed a different light on the construction of Ainu identity, by locating it within the broader contemporary discourse on Japan's national identity. It argues that the emergence of Ainu subjectivity in the public discourse in the 1970s can be partially attributed to the domestic struggle between the conservative and the progressive camps over the definition of Japan's identity. The paper analyzes both sides of the discourse and examines the role of the Ainu 'other' within this construction. It proceeds further to examine the challenge that the emergence of Ainu subjectivity has posed to Japan's politics, mainly in the context of the 'Northern Territories' dispute. The concluding part briefly examines the policy responses aimed at addressing these challenges. ${ }^{1}$
\end{abstract}

Key words: Ainu, Japan, identity, indigenous, colonialism, Northern Territories

\section{Ainu within Modernizing Japan's Identity}

When the geopolitical interests of pre-modern Tokugawa Japan and the Russian Empire collided for the first time in the second half of the eighteenth century, Ainu were in the centre of the dispute. From the Japanese side, the hierarchical understanding of the 'self', the Ainu, and the Russian 'others' has played a central role in the conception of the Russian threat and in the development of policies aimed to counter this threat. Namely, the Russian expansion of influence over the native residents of the border area was seen as an expansion of a superior culture, conducted through enlightenment and amicable policies. These factors were seen by parts of the Japanese elite as containing the dangerous 
possibility of a voluntary embrace of the rule of the Russian Empire by the Ainu (Akitsuki 1987). As such, the directives given by the Edo (Tokyo) shogunate to the Matsumae clan, which acted as an intermediary between the central government and the Ainu after the Ainu revolt of 1789 , emphasized the need to educate the natives to prevent the spread of Russian influence (Takakura and Harrison 1960: 51). In other words, in a simplified hierarchical construction of the self and the two 'others', Russia and Japan occupied relatively equal status in terms of their cultural values, while the Ainu, who were seen as potentially subjected to enlightenment by either Russia or Japan, were at the lowest step of this cultural hierarchy.

Japan's semi-forced socialization into Western international society in the second half of the nineteenth century led to an internalization of two sets of interrelated but substantially different modes of normative behaviour. On one hand, Japan aimed to gain the status of a 'civilized' nation and engaged in cordial relations with the Western powers. At the same time it adopted coercive imperialist policies towards peoples it considered 'uncivilized'. These policies were seen as an integral part of the newly acquired 'civilized' state identity (Suzuki 2005: 139).

Ainu became the first direct subjects of Japan's modern colonialism, as the colonization process of their lands began almost simultaneously with the establishment of the new Meiji government that toppled the feudal Tokugawa shogunate. In the 1860s, during the first years of Japan's 'socialization' into the imperialist international society and a few decades prior to the emergence of Japan's version of Orientalism (Tanaka 1993), when the debates over Japan's place in the world were in their embryonic state, the island of Hokkaido and adjacent islands (including what a century later came to be known as 'Northern Territories'), all inhabited by different Ainu groups, were incorporated into Japan proper, becoming the 'Northern Gate of the Empire'. The Meiji government embarked on a mission to colonize the territories and educate the natives, largely based on the American experience of 'developing' Indian lands (Siddle 1996: 55-56). The Kurile Ainu, who along with the Hokkaido Ainu became subjects of the Japanese Empire, met a similar fate. As one of the Meiji-era Japanese surveys of the islands shows, in 1872 there were around 70 Ainu living on the two largest islands currently disputed by Japan and Russia, Kunashiri and Etorofu, and Ainu constituted one-third of the population of the Kuriles (Chishima in Japanese) (Sasamori [1893]1988). In 1884, the island of Shikotan, initially uninhabited, was populated through a forced transfer of the 
indigenous population of the northern Kurile island of Shumushu, ${ }^{2}$ as the Meiji government did not trust the russified Ainu to reside at the northern gate of their empire's northern frontier (Kikuchi 1994: 58-59). Relocation to a fundamentally different environment, combined with policies of Japanization and attempts to convert the traditional hunters into farmers, had severe consequences for this 97-strong Ainu community, forcefully detached from their traditional way of life. Within only six years after relocation, the size of the community had declined by 50 per cent, to 49 members in 1890 (Kaiho 1974: 84-87).

In terms of the Ainu's place in Japan's identity, the Japanese conception of the Ainu allowed for mobility from the inferior realm of barbarian to the realm of the civilized, as Japan itself was still subject to unequal treatment by the 'civilized' nations of the West. As such, it was a combination of the two modes of the colonial encounter with the 'other' outlined by Todorov (1984: 42): the Ainu were perceived as different and inferior, but at the same time susceptible to assimilation through education to become an integral part of the Japanese 'self'. As Japan itself was in the process of self-education towards 'civilization', denying the Ainu the possibility of becoming equal subjects of the Emperor would mean denying Japan the possibility of becoming an integral part of the realm of civilized nations. It must be noted that the discourse on Japan's ethnic structure in the imperial years has been rather unstable and has undergone a number of significant fluctuations between ethnic homogeneity and heterogeneity (see Oguma [1995] 2002 for a detailed discussion). Within this context, the ethnic difference or similarity between the Ainu and the mainland Japanese (wajin) was a subject of continuous academic debate among contemporary anthropologists. While some argued for different ethnic origins, others countered by presenting linguistic and cultural arguments that found in Ainu customs traces of ancient customs and religion (Shintō) of Japan and in the Ainu language remains of archaic Japanese (Oguma [1995] 2002: 73-86).

However, in cultural terms, the Ainu 'backwardness' and the need to 'civilize' them through education were taken for granted. In other words, the ideas of historical progress and enlightenment imported from the West during the nineteenth century resulted in reinterpretation of the Ainu difference in terms of time rather than space (Morris-Suzuki 1998: 9-34). The Ainu society, which earlier was viewed as inferior and different but existing in a coeval temporal space, came to be seen as backward and representing Japan's own past in the modernist and 'civilized' cosmology. While earlier, education of the Ainu was seen simply as a 
strategic tool to prevent the spread of Russian influence, now adaptation of the customs of 'civilized' Japan became the main condition for achieving the status of a fully equal human. Forced assimilation of Ainu into the new and modern Japanese nation as an integral part of what later became the 'family' of the Emperor's subjects, became one of the pillars of Japan's colonization policies (Hashimoto 1987: 271).

Later, during Japan's imperial expansion in the Asia Pacific, the colonization of Ainu lands came to be represented as an integral part of the broader modern development of the Japanese (Yamato) race, as one of the first steps of the 'pioneering' (kaitaku) project, which included Manchuria, Korea and the South Pacific islands (Takakura 1942: 171). This contextualization of the 'development' of Hokkaido and adjacent islands within the broader project of colonial expansion is not surprising. The process of colonization in Hokkaido through the state-organized dispatch of 'pioneers' was similar in its rationale and implementation to that followed later in Taiwan, Manchuria and Korea. Furthermore, the assimilation policies applied to Ainu served as a source of information for subsequent policies of Japanization in Korea (Siddle 1996: 145; Oguma 1998: 55).

During the last days of the Asia-Pacific War and in the few weeks following Japan's surrender, parts of the formerly Ainu territory, namely, Sakhalin and the Kurile archipelago including the four islands of Habomai, ${ }^{3}$ Shikotan, Kunashiri and Etorofu, which later came to be known in Japan as the 'Northern Territories', were occupied by the Soviet Union. The unilateral annexation of the islands in 1947 was followed by expulsion of the remaining Japanese residents, among them a number of Ainu. A grassroots movement for the return of the occupied territory by Hokkaido residents started almost immediately after the Soviet occupation, although the embrace of the irredentist cause by the Japanese government occurred much later and crystallized as the quest for the return of the four islands only in the 1960s. The question of the Ainu as the original owners of the islands, however, did not surface in the domestic discourse during the formative years of the territorial dispute and the conception of the islands as Japan's inherent territory became an integral and unproblematic aspect of Japan's policy vis-à-vis the Soviet Union.

In the first decades after Japan's defeat in the Asia-Pacific War and its surrender and rebirth as a new democratic nation, the Ainu, along with other colonized people, were largely excluded from the narrative on Japan's past and present. The school textbooks, in their brief references 
to Meiji-era northward expansion, maintained the pre-1945 modernizing paradigm and ignored the disastrous effects of Japan's expansion on the Ainu (Nishino 2007:5). Other scholarly and popular texts related to the Northern Territories also noted briefly that the territories were acquired peacefully by Japan and over the years developed by Japanese, focusing on the dispute solely in terms of a bilateral issue between Japan and Russia (for example, see Taoka 1962). This tendency did not necessarily reflect Japan's peculiar denial to face its past but has been consistent with the broader international consensus regarding the place of indigenous peoples in independent nations. As reflected in one of the principal conventions regarding indigenous peoples, the International Labour Organization's Convention No. 107 (ILO 107), drafted in 1957, assimilation and integration are seen as the best way to protect the well-being of indigenous peoples. ${ }^{4}$ Furthermore, the Ainu community itself was generally oriented towards elimination of discrimination through further integration into Japanese society and did not envisage a self-identity as a distinct nation or ethnicity (Siddle 1996: 151-61). Thus, in the 1950s, a number of Ainu expelled from the Kuriles by the Soviet forces participated in the grassroots irredentist movement for the return of the islands along with other wajin former residents, as 'living witnesses' of Japan's peaceful acquisition and development of these territories (Harrison 2007: 73-74).

\section{The Struggle over Japan's Identity and the Emergence of Ainu Subjectivity}

The question of Japan's colonization of the Ainu did not appear in the public discourse after Japan's defeat in the Asia-Pacific War and the conquest continued to be narrated within the modernizing paradigm. The broad narrative on Ainu that involved re-evaluation of Ainu culture and the portrayal of Ainu as victims of Japan's colonization as well as the quest of the Ainu themselves for recognition as indigenous people appeared in Japan's public discourse in the early 1970s. In current scholarship, this politicization and the sudden visibility of the Ainu issue have been attributed to different social and political trends. Some argue that the appearance of the Ainu in the public discourse should be seen as a sub-product of the discourse on the 'suffering of Asia' that emerged in Japan during the Vietnam War. It has been argued that the anti-war sentiment in Japan and expressions of solidarity with the peoples of Vietnam, Laos and Cambodia rekindled not only memories of Japan's 
own victimization of other peoples in Asia but also a discovery of an 'internal Asia' consisting of Ainu and Korean residents in Japan (Oguma 2007: 208-11). An actor-based exploration of the process of reconfiguration of Ainu identity in the 1970s emphasized the role of domestic social movements of the 1960s in facilitating the emergence of the Ainu political movement (Siddle 1996), but also noted the rise of international interest in the question of indigenous people and subsequent Ainu exposure to it as one of the dominant factors in the rise of Ainu ethnic consciousness (Siddle 1996; Harrison 2007; Larson et al. 2008).

However, a different light can be shed on the debate on the place of the Ainu as well as the emergence of the Ainu voice in the public discourse by examining the debate in the context of the broader domestic struggle between the conservative and progressive camps over the nature of Japan's national identity. There is no doubt that the number of violent acts of protest conducted by certain radical Japanese groups in the 1970s in the name of Ainu liberation played an important role in attracting public attention to the 'Ainu problem' (Siddle 1996: 165). The structure of the discourse, which focused on a critical re-evaluation of Ainu history and culture by Japanese progressive intellectuals in the 1970s, shows, however, that it was an integral part of broader domestic struggles over the nature of Japan's identity. Namely, 'Ainu' as a symbol of something fundamentally different from contemporary Japan, were mobilized to create a discursive intervention into the rising conservative narrative on Japan's ethnic and cultural homogeneity (nihonjinron, or the theory of Japaneseness) and the unquestioning positive evaluation of economic progress in general and Japan's development specifically (for a critical review of nihonjinron, see for example, Dale 1986; Aoki 1999; Befu 2001). In other words, by focusing on the Ainu, the progressive critique constituted an attempt to counter two homogenizing identity discourses championed by the conservatives: the domestic construction of Japan as a homogenous nation and the more general discourse of liberal capitalism.

The critical narrative was not restricted to criticizing the history of Japan's conquest of Ainu lands, but engaged in detailed depictions of continuing acts of discrimination against the Ainu and the persistent structure of 'aggression' and 'exploitation', undermining the conservative construction of Japan as a homogeneous nation (for example, Ogawa 1974: 36-37; Hanazaki 1977: 61; Narita 1981: 66). At the same time, within the critical agenda, the 'liberation' of Ainu came to be represented as an integral part of the broader liberation of Asian and 'Third World' peoples 
(Hanazaki 1977: 62). However, the liberation of the Ainu was not seen as a goal in itself but as an integral part of the search for an alternative future not dominated by economic development, as an escape from the path dictated by the norms of the market economy. The 'liberation' of the Ainu from the atrocities and degradation visited on them by modernity was argued to be the only means to 'overcome' the dead end of modernization in order to 'open a door' to the future (Hanazaki 1977: 63). The critical discourse engaged in a radical reinterpretation of Japan's 'development' of Hokkaido and its 'enlightenment' of the indigenous population. The history of the Ainu after the advent of modernization and colonization came to be represented as a tragedy in contrast to the triumphant modernizing discourse. Following the paradigms established by the decolonization process, the Japanese (wajin) came to be portrayed as invaders, who paid no respect to the customs and habits of the indigenous population and forced their own 'modern' value system on the Ainu (Ogawa 1974: 37; Matsui 1972: 256-59).

In this attempt to undermine the two homogenizing discourses of the conservative nihonjinron, the narrative went beyond a simple critique of Japan's history and contemporary societal discrimination against the Ainu. Importantly, it relocated Ainu difference from a temporal back to a spatial one, and presented the Ainu 'other', unspoiled by modernity, as coexisting with contemporary modern Japan. In the words of one of the writers, 'the Ainu live in the present and together with them lives the Ainu culture' (Ehara 1980: 63). This construction was enhanced through visual images of Ainu leading a 'traditional' way of life that appeared in a number of publications (for example, Kitahara 1983: 1) and extensive narration of Ainu culture and customs, not as a matter of the past but as a contemporary reality (for example, Fujimura 1982).

The coeval but at the same time archaic society of Ainu served as an antithesis to the modern world, a space in which the world of the gods, the world of humans and the world of nature existed in mutual reverberation, a space narrated as the source of inspiration for overcoming the 'pathology' of modern society (Hanazaki 1977: 62). In its critique of Japan's modernity, the narrative contrasted the quiet life of the Ainu village (kotan) with 'featureless' modern buildings and mourned the gradual disappearance of culturally 'pure' Ainu and 'inherent' Ainu culture and customs (Ogawa 1974: 36). As such, through the embrace of coevality of the Ainu with the Japanese, the progressive narrative seemingly overcame the hierarchy embedded in the temporal construction of the difference. However, it is doubtful whether this constituted an 
admission of a dialectical relationship between the subject and the object and actual engagement with the 'time of the other' as argued by Fabian (1983: 153). Basically, categorizing the Ainu as pure and innocent 'natives' denied the existence of Ainu modernity, as lived by the members of the community since their forced incorporation into modern Japan. Arguably, more than an engagement with the time of the 'other', this celebration of the native, unspoiled by modernity, resembles more the eighteenth- and nineteenth-century European literature of the 'noble savage', which also engaged in reversion of the existing hierarchy between the 'self' and the 'other', but did not grant subjectivity to the 'native'. Like the writings of earlier - but also more recent -European thinkers, who saw in the 'native' representatives the lost Eden or the golden age of human society or the 'innocence' lost by the modern society driven by Enlightenment paradigms (Liebersohn 1994: 746), the Ainu culture was objectified to represent the simplicity, purity and harmony with nature lost in modern Japan's society.

This attempt to place the Ainu 'other' back in the realm of spatial and ethnic difference led to a counter-attack from the proponents of the (conservative) nihonjinron discourse. They countered this attempt to destabilize the construction of a homogeneous Japan by arguing that ethnically and culturally Ainu are an integral part of the Japanese race. This counter-narrative sought to conceal the recent history of conquest, resistance and discrimination relative to the Ainu by shifting the focus of the debate away from modern history to the prehistoric Jomon period (c. 10,000 BC to $300 \mathrm{BC}$ ) and at the same time asserting the same ethnic origins for both the Japanese and the Ainu.

A special section in the popular Chūo Kōron journal in March 1982, titled 'A new view on nihonjinron', illustrates the attempt to absorb the Ainu 'other' into the Japanese 'self', by shifting the focus from modern to ancient time frames. The special section included articles written by authoritative academics from a variety of related disciplines, all of which in one way or another denied the ethnic difference ascribed to Ainu by the progressive narrative. One article argued that the history and origins of the Ainu should be viewed in a broader time frame reaching back to the prehistoric period. Hence, by providing a broad historical analysis of the Ainu and the Japanese (Yamato) people, it was argued that both peoples have cognate cultural and ethnic origins and share a common history dating back prior to the annexation of Hokkaido. The article concluded by stating that the nineteenth-century annexation of Hokkaido should be seen not as a conquest but as an act of reunification 
of the nation (Takahashi 1982: 295-98). An anthropological review of the origins of the Ainu argued that the Ainu are of Mongoloid origin and in their physical constitution are very similar to the Japanese (Hanihara 1982). While the argument was presented very cautiously and the author was careful to avoid making any explicit statements regarding the relationship between the two groups, the implication that both the Ainu and the Japanese are of the same ethnic origin is rather obvious. The special section also included an article written by Umehara Takeshi, one of Japan's leading scholars of Japanese philosophy and the first Director General of the government-affiliated International Research Center for Japanese Studies. In his contribution, Umehara argued simply that any imputation of ethnic difference between the Japanese and Ainu is a recent and mistaken invention. Through a lengthy linguistic analysis stressing the similarity of the two languages, Umehara attempted to refute this 'recent myth', and like the other contributors, argued for the same origin of both the Ainu and the Japanese (Umehara 1982).

Similar conceptions could be also observed in the works of one of the most popular writers of post-war Japan, Shiba Ryōtarō, who subscribed to the conservative nihonjin ron narrative by describing the Ainu as the 'civilizational ancestors' of the Japanese. Shiba argued that Ainu are indisputably Japanese, descendants of people who 'stubbornly' continued to preserve the prehistoric Jomon lifestyle despite the advent of Yayoi civilization (circa $300 \mathrm{BC}-250 \mathrm{AD}$ ) and all that transpired in the centuries that followed ([1992] 1997: 145.) Throughout his book on the history of Hokkaido, Shiba emphasizes the ethnic and cultural continuity between the Ainu and modern Japanese and repeats the argument that the conquest of the Ainu lands has not been a 'bloodstained struggle' between a conquering and an indigenous people, but little more than a brotherly competition between different lifestyles (ibid: 65). This attempt to incorporate the Ainu within the ethnic construction of the Japanese and to obscure the history of conquest and discrimination through re-introduction of one of the theories from the nineteenth century was criticized. It was deemed false and pseudo-scientific (Hagino 1983) and denounced as a new form of exploitation of the Ainu for conservative neo-nationalism (shin kokkashugi) seeking to deny any Japanese responsibility for the miseries brought upon the Ainu by nineteenth-century colonialism (Hanazaki 1986: 103-05).

In spite of the questionable nature of the scientific basis for the conservative narrative and its rather obvious motive to conceal the recent history of subjugation of the Ainu, the cultural construction of the Ainu 
that emerged from the conservative narrative strikingly resembled the one advocated by the critical discourse as it emerged within a broader context that was fundamentally different from the late nineteenth-century debates about Japan's identity. Namely, 'culture' and 'tradition', which were widely perceived as obstructing progress in the second half of the nineteenth century, now had attained an almost absolutely positive value in the nihonjinron discourse. Since the Ainu had come to represent the 'original' Japanese culture, now they were elevated from the inferior position of backward people to the status of superior carriers of the 'foundation of Japanese culture' that has been continuously present within Japanese thought and religion (Umehara 1984: 38) and whose 'blood flows in the veins of the majority of Japanese today' (Umehara [1982] 1985: 7; Shiba [1992] 1997: 9-12). As such, the narrative of the Ainu as an animist people living in harmony with nature that emerged from the conservative writings has been almost identical in its structure to the one propagated by the progressives. However, rather than juxtaposing Ainu and Japanese cultures, it has narrated the Ainu as an integral part of Japan's ancient culture, the sameness emphasized through juxtaposing both cultures with the most dominant 'other' in the construction of modern Japan's identity, namely 'the West' (Umehara 1984: 38-51).

This elevation of Ainu to the status of 'original Japanese' and the carriers of the inherent Japanese culture within the meta-discourse of nihonjinron, which argued for Japanese cultural uniqueness as the source of its successful modernization, resulted in a rather paradoxical inversion of the hierarchy between the Ainu and the Japanese in cultural terms. However, unlike the progressives who engaged in a critique of the modernizing paradigm and positioned the Ainu outside of the borders of modernity, here it remained contained within the meta-narrative of civilization and progress. As such, since the nihonjinron argument tried to explain and affirm Japan's post-war economic success through cultural characteristics, Japan's rapid post-war development came to be attributed to the 'hunting spirit' of the Ainu as opposed to the agricultural character of the Japanese (Umehara [1982] 1985: 10). In other words, Ainu culture, perceived as the opposite of progress and modernity from the early years of colonization well into the 1970s, was reconceptualized as the source of Japan's development and progress in a discourse that narrated economic development in terms of culture and tradition.

To a large extent, not only the conservative conceptions of the Ainu culture but also the progressive ones reflected the late nineteenth-century debates that sought to explain the origins of the Japanese people through 
the language of modern anthropology (for example, see Oguma [1995] 2002 and 1998). Hence they should be seen more as a reinterpretation and appropriation of earlier academic debates that failed to reach a consensus regarding the ethnic origin of the Japanese people rather than a radically new understanding of the Ainu/Japan nexus. However, in the context of the contemporary struggle to define Japan's identity, this paradoxical relocation of the Ainu to the temporally coeval and hierarchically superior realm - a relocation that emerged from both the conservative and the progressive narratives - enabled Ainu participation in the public discourse, not as inferior 'natives' but as equal or even superior subjects.

In general, the argument of the members of the Ainu community who appeared in public debates merged with the progressive discourse in criticizing the dominant conception of Japan as a homogeneous nation, arguing for a distinct ethnic Ainu identity and presenting a historical counter-narrative that depicted Ainu history under Japanese domination as a history of aggression, discrimination, oppression and subjugation. The 'indigenous voice', as manifested in the writings and speeches of public figures of Ainu origin such as Yūki Shōji, Chikappu (Chikap) Mieko, Narita Tokuhei, Kayano Shigeru and others, clearly subscribed to the progressive view of the history of Japan's northward expansion and located the Ainu 'self' in opposition to the colonizing Japanese. They argued that the history of Japan's northward expansion was a history of colonialism, betrayal of trust, aggression and subjugation. However, we must note that in terms of cultural identity, the discourse of the Ainu activists has been virtually identical to the conceptions of the 'pristine' Ainu culture shared by both the progressive and conservative discourses. In other words, the Ainu activists, in their struggle for a distinct identity, refused to, or more precisely, could not engage the time of the 'self' but were forced to engage in 'self-orientalism'. There are a number of factors that led to this continuous dependence on Japanese sources and conceptions for definition of Ainu culture, among them the lack of original Ainu documents resulting from the absence of a written language and the fact that the actual struggle for Ainu identity was led by the 'third generation' of Ainu who were immersed in Japanese culture and had neither experience of Ainu culture nor the initial sense of belonging (Irimoto 1999: 198). As such, the Ainu 'voice' joined in with the progressive critique of the past and the political and social present and embraced the 'noble savage' cultural identity. Obviously the alternative - the contemporary culture of the Ainu, which differed little from the Japanese one - would have erased the very same distinction it was struggling to create. 
The historical narrative of the Ainu activists utilized the 'traditional' construction of the Ainu as backward and inferior, and through inversion of the hierarchy, articulated their distinct identity. Echoing but also reversing the paradigms of Japan's colonial discourse in its structure and terminology, the Ainu narrative came to bear a striking resemblance to the Chinese and Korean depictions of Japanese imperialism. For example, predating the emergence of the infamous 'comfort women' controversy in the context of Japan's colonialism and imperialism in Asia by almost two decades, the Ainu public figures argued that Ainu women were used as 'comfort women' by the Japanese invaders, who were the actual 'barbarians' (Narita 1973: 331).

\section{Ainu and the 'Northern Territories'}

The challenge of the Ainu rights movement to Japan's domestic politics has been examined in a number of scholarly works (for example, Siddle 1996; Levin 1999). Harrison (2007) explores the possibilities for solving the 'Northern Territories' dispute from the perspective of Ainu rights. This part, however, focuses on the challenge of the Ainu discourse to the officially endorsed construction of Japan's victimhood vis-à-vis the Soviet Union, which, by the 1970s, became an important part of the domestic mainstream discourse (for details see Bukh 2009).

The 'Northern Territories' dispute and the related sense of Japanese victimhood also became an important part in the process of inversion of hierarchies examined in the previous section. For example, Japanese mainstream critique of the Soviet oppression of ethnic minorities and suppression of their rights through imposition of Russian language and culture was revised to question Japan's own policies of assimilation and suppression of the Ainu culture (Yūki 1997: 72-73). While the Japanese mainstream condemned the Soviet Union for 'stealing' the 'Northern Territories' from Japan, the historical narrative that emerged from Ainu activists opposed this conception by arguing that it was Japan that was the aggressor that initially stole the territory from the Ainu (in Yūki 1997: 58 and Yamamoto 1992: 12). Thus, Ainu activists argued that the 'Northern Territories' are neither Soviet nor Japanese, but are an integral part of historical Ainu territory. Similarly, while the mainstream irredentist discourse argued that Japan was a victim of Soviet aggression, in the Ainu narrative the conception of the islands as Japan's 'inherent territory' was argued to be a symbol of Japanese aggression against the Ainu. Criticizing this mainstream conception, the Ainu activists argued 
that until the end of the war, the Kurile Islands and Sakhalin were nothing more than a colony, an 'outside territory' (gaichi) (Narita 1973: 330). Stating that the Ainu had never rented or sold Hokkaido nor the Kurile Islands to the Japanese, the indigenous voice and a number of non-Ainu (wajin) intellectuals continuously criticized the government-sponsored movement for the return of the Japanese 'inherent territory', the 'Northern Territories', for its ignorance of the fact that before the invasion of the Japanese, it was the land of the Ainu (for example, Narita 1973: 329, 1981: 96-97; Kayano 1980, 1986: 110, 1997: 5-6; Yamamoto 1992; Nomura 1993; Yūki 1997: 57-96).

The 1884 forced relocation of Shumushu Ainu to the island of Shikotan, now one of the 'Northern Territories' islands, became an important part of the historical narrative on Ainu victimhood and in the critique of the mainstream irredentist movement. The tragedy of the Shumushu Ainu who, at the time of their forced relocation to Shikotan were deeply russified in terms of culture, language and religion, became part of the narrative regarding the suffering of the Ainu at the hands of the Japanese and one of the historical incidents in the construction of the counter-discourse on 'Northern Territories' (for example, Kaiho 1974; Yamamoto 1992: 88; Hirayama 2005: 96-98).

Notably, the appeal to the 'Northern Territories' as a symbol in the construction of Ainu identity was not univocal. Possibly reflecting the at-times explicitly stated dependence of the Ainu struggle on mainstream politics (for example, see Kayano 1994: 110) or resulting from purely pragmatic calculations, the position on the 'Northern Territories' issue adopted by the Hokkaido Utari Association (Utari), the main representative organization of the Ainu, has been quite ambiguous. Arguably, the agenda of the Utari reflects its mission to rescue Ainu history from the modernizing narrative, its opposition to the 'homogenous nation' paradigm and its dependence on government funding and the need to ally with mainstream politicians. Thus, in 1982 it passed a resolution that suspended (horyu $)$ Ainu land ownership claims to the four disputed islands. In the following year, however, the Utari published a collection of documents regarding prior habitation of the Kurile Islands by the Ainu (cited in Siddle 1996: 183) and passed a resolution that called for the Japanese government and the Hokkaido prefectural authorities to recognize Ainu as the prior inhabitants (senjūsha) of the Kurile Archipelago (see CCCP Camera blog). In August 2002, Utari decided to adopt a resolution that would officially call for recognition of Ainu prior habitation rights on the islands of the 'Northern Territories' during its general meeting in 
spring 2003 (Asahi Shimbun, 30 August 2002: 26.) This resolution, however, has never materialized. Similarly ambiguous was the position taken by Kayano Shigeru, one of the leading figures in the Ainu movement who became the first Ainu to sit in the Diet. After getting elected to the Diet in 1994 Kayano stated on a number of occasions (for example, at House of Councilors, Cabinet Committee meeting, 24 November 1994 and at the meeting of the Committee on Okinawa and Northern Territories, 02 December 1997) that the 'Northern Territories' had been Ainu territory and now, two strong states, Russia and Japan, were debating the future of the islands 'above the heads' of the 'original owners'.

Notably, this conception of the territorial dispute contradicted the official position of the socialist party, Kayano's political base. Japan's Socialist Party (from 1996 onwards, the Social Democratic Party of Japan) embraced the Ainu issue in its struggle with the conservative Liberal Democratic Party (LDP) already in the 1970s. At the same time, however, it adhered to the 'Japan's inherent territory' conception of the 'Northern Territories' and did not dwell on the ramifications of the revision of the history of Japan's northward expansion that it championed for the territorial dispute (see for example, Gekkan Shakaitō 1974). When interviewed for the party organ, Kayano's statement regarding his political goals and ambitions referred to Japanese colonization of the Ainu lands as an act of aggression but at the same time omitted the 'Northern Territories' issue and explicitly limited the geographical scope of Ainu lands to Hokkaido (Kayano 1994: 111).

References to the 'Northern Territories' emerged mainly as individual views of various Ainu leaders, from non-affiliated activists and from smaller and more independent Ainu organizations. Nevertheless, however limited in scope, the issue of the Ainu did become part of the domestic political and public discourse on the 'Northern Territories'. Many of Japan's left-leaning historians in charge of compiling school history textbooks came to share the Ainu perception of the dispute and consistently refused to insert the reference to the 'Northern Territories' as 'inherent Japanese territory' in the school history textbooks (Ienaga 1993: 63-66). Since the early 1980s, the progressive daily Asahi Shimbun has carried multiple articles and opinion pieces questioning the notion of the 'Northern Territories' as Japan's 'inherent territory', calling for the need to recognize the Ainu as their historical inhabitants and to address the question of Ainu rights vis-à-vis the disputed islands. On the eve of the 1988 Soviet Foreign Minister Shevarnadze's visit to Japan, the Asahi Shimbun reported a demand issued by a group of Ainu activists called 
'Ainu National Congress' (ainu minzoku kaigi), that the government include Ainu representatives in the bilateral talks (Asahi Shimbun, 17 December 1988). In September 1991, one of the Ainu activists, Chikappu Mieko, was among the members of the group that visited the disputed islands as part of a tour organized by 'Peace Boat', a leftist Japanese non-governmental organization. Besides explicitly positioning herself in talks with local Russian residents not as a Japanese, but as an Ainu, a representative of the 'original owners' of the islands, Chikappu criticized the hypocrisy underlying the Japanese irredentist movement and the conception of the islands as Japan's 'inherent territory' (in Yamamoto 1992: 140-46).

Obviously, the appropriation of the irredentist cause and the vision of an Ainu state on the 'Northern Territories' by parts of the Ainu community as well as the presentation of Ainu as culturally and ethnically distinct from the Japanese in this counter-discourse had significant implications for Japan's quest for the return of the 'Northern Territories'. Besides questioning the validity of the mainstream historical narrative on the 'inherent territory', the Ainu discourse also undermined the conception of the irredentist cause as a 'national mission' and the historico-cultural argument that justified Japan's preoccupation with the return of the islands through an appeal to a 'unique Japanese concept of national territory', in which 'natural, racial, linguistic and cultural boundaries must coincide with political and administrative borders' (Kimura 1980: 709, emphasis added).

\section{Policy Responses to the Ainu Challenge}

Despite the above examined attempts to expand the Ainu issue to the political arena, the successes of the Ainu activists and other supporters of the cause remained contained within the realm of the historical, social and cultural. While first steps to improve the social position of the Ainu were taken by the Hokkaido government already in the 1970s, on the national level the Ainu activities yielded results only in 1997, when the process of revising the colonial legislation that designated the Ainu as 'former natives' abolished this almost hundred-year-old law and enacted the Act for the Promotion of Ainu Culture, the Dissemination of Knowledge and Education regarding Ainu Traditions. Formally, this law interrupted the discourse on Japanese ethnic homogeneity and officially elevated the Ainu from the realm of inferior barbarian to a status of an equal ethnic entity. At the same time, however, the report of the Expert Group on which the law was based, largely followed the nihonjinron conception of the Ainu culture. It contained the Ainu within 
the realm of Japanese identity by stipulating their status as indigenous people within the realm of Japan's 'inherent territory' and glossed over the history of invasion, colonization and forced assimilation (Siddle 2002: 408; Satō et al. 2009: 23).

More significant change occurred only a decade later, when in June 2008, a month before Japan hosted the G-8 summit on Hokkaido, both Houses of the Diet unanimously adopted a resolution that noted the history of discrimination against the Ainu and recognized them as the indigenous people of Japan, 'prior habitants of the northern part of the Japanese islands, especially Hokkaido'. At this point, the exact ramifications of this resolution, fostered by political calculations of little relevance to Ainu per se (Suzuki 2008a: 68-69), for Japan's Ainu policy are still to be seen. A report published by the Expert Group on Ainu Policy in July 2009 goes much further than the one of 1997 in its recognition of Ainu as indigenous people with their own distinct identity and the past and present misfortunes resulting from the state's policy. At the same time, its policy recommendations are limited to cultural and social aspects. In terms of granting political rights to Ainu, the report mentions briefly in its last paragraph that this issue should be studied 'prudently' as mid- and long-term policy issues (Satō et al. 2009). It also must be noted that apparently the Diet resolution that recognized Ainu as indigenous people was achieved on a basis of a certain tacit understanding shared by both the members of the Diet and Utari leadership. Namely, it was agreed that the recognition of Ainu rights would not entail any financial compensation or recognition of Ainu land claims and would be limited mainly to support for Ainu exercise of their cultural rituals (Suzuki 2008a: 54, 2008b: 71), restricting the exercise of indigenous rights to non-political issues. Furthermore, it seems that in the process, the Utari agreed not to tolerate any 'splittist' (kokka bunretsu) claims emerging from within its ranks (Suzuki 2008a: 55), explicitly distancing itself from the 'Northern Territories as part of Ainu lands' argument and other political demands supported by certain Ainu groups. As such, it is doubtful whether the quest for Ainu identity will ever be able to go beyond the cultural and social boundaries, determined to a large extent by the Japanese political discourse.

Alexander Bukh is an Associate Professor of International Relations at the Graduate School of Humanities and Social Sciences, University of Tsukuba in Japan. (abukh70@gmail.com) 


\section{NOTES}

1 Parts of this article appeared in Chapter 4 in: Alexander Bukh, Japan's Identity and Foreign Policy: Russia as Japan's 'Other'. London and New York, Routledge (2009).

2 As the result of the conclusion of the 1875 Saint Petersburg Treaty between Japan and Russia, Japan gained control over all of the Kurile chain in exchange for giving up claims to Sakhalin. Shumushu is the northernmost island in the Kurile chain located in close proximity to the Kamchatka Peninsula.

3 Habomai is actually a small archipelago consisting of seven principal islands.

4 The revised convention (ILO 169), which argued for respect for cultures and traditions of indigenous people, appeared only in 1989.

\section{REFERENCES}

Akitsuki, Toshiyuki 1987. 'Edo Jidai ni Okeru Nijonjin no Roshiakan' (Japanese view of Russia during the Edo period). In Ryohei Yasui (ed), Nihon to Roshia (Japan and Russia). Tokyo, Waseda University.

Aoki, Tamotsu 1999. Nihonbunkaron No Henyo (Transformation of Nihonbunkaron). Tokyo: Chuokoron-shinsha.

Asahi Shimbun 1988. 'Hoppōryōdo henkan kōshō ni ainu mo sanka o' (Ainu demand to be included in the negotiations related to the return of the Northern Territories), 17 December.

Befu, Harumi 2001. Hegemony of Homogeneity. Melbourne: Brown Prior Anderson.

Bukh, Alexander 2009. Japan's Identity and Foreign Policy: Russia as Japan's 'Other', London: Routledge.

CCCP Camera blog. Accessed 10 October 2010 at www.ne.jp/asahi/cccp/camera/HoppouRyoudo/Naiyou/Senjuuminn.htm.

Dale, Peter N. 1986. The Myth of Japanese Uniqueness. Sydney: Croom Helm and Nissan Institute for Japanese Studies.

Ehara, Kota 1980. 'Ainu No Kotoba/ Kotoba No Tamashi' (The Ainu language, the soul of the language). Asahi Journal 22, no. 28: 61-63.

Fabian, Johannes 1983. Time and the Other: How Anthropology Makes its Object. New York: Columbia University Press.

Fitzhugh, W. W., and S. O. Dubreuil (eds.) 1999. Ainu: Spirit of a Northern People. Los Angeles: Perpetua Press.

Fujimura, Hisakazu 1982. '"Kokoro" No Bunka' (Culture of the 'heart'). Chūō Kōron 97, no. 13: 303-11.

Gekkan Shakaitō 1974. 'Ainu Minzoku Seisaku' (Policy regarding the Ainu people). 207: 223-26.

Hagino, Munemi 1983. 'Umehara Takeshi shi no dōkeiron e no gimon' (Questioning Umehara's 'same origin' theory). Chūō Kōron 98, no. 4: 195-203.

Hanazaki, Kohei 1986. 'Gendai nihonjin ni totte minzokujikaku to wa' (What national self-awareness means for modern Japanese). Sekai 483, no. 1: 99-117.

- 1977. 'Sabetsu No Uchi in Aru Ainu No Jinken Kaifuku' (Restoring the human rights of discriminated Ainu). Asahi Journal 19, no. 35: 61-63.

Hanihara, Kazuro 1982. 'Shizen Jinruigaku Kara Mita Ainu' (Ainu as seen from natural anthropology). Chūō Kōron 97, no. 13: 275-89.

Harrison, Scott 2007. 'The Indigenous Ainu of Japan and the 'Northern Territories Dispute'. MA Thesis, Department of History, University of Waterloo. Accessed 14 December 2008 at http://uwspace.uwaterloo.ca/bitstream/10012/2765/1/ Scott\%20Harrison_GSO_Thesis.pdf. 
Hashimoto, Susumu 1987. 'Ainu jinken sengen no tameni' (For Ainu human rights declaration). Sekai 499, no. 3: 265-79.

Hirayama, Hiroto 2005. Ainu Hoppōryōdo gakushū ni charenji (Challenging the study of the Ainu and the Northern Territories). Tokyo: Akashi Shoten.

Ienaga, Saburo 1993. Misshitsu kentei no kiroku (Proceedings of the behind the closed doors certification process). Tokyo: Meichou kankoukai.

Irimoto, Takashi 1999. 'Ainu minzoku mondai' (The problem of the Ainu nation). In K. Miyamoto and Y. Shimizu (eds.), Bunka jinruigaku kōgi (Lectures on Cultural Anthropology), pp. 190-203. Tokyo: Yachio.

Kaiho, Yōko 1974. 'Kindai ni okeru ainu no kyousei ijū' (Forced relocation of Ainu in modern Japan). Rekishi hyōron 292: 79-90.

Kayano, Shigeru 1997. Ainu minzoku kara mita kindai nihon (Modern Japan as seen from the Ainu people), Tokyo, Chūō University.

- 1994. 'Ima koso nihojin to taitō no hanashiai o shitai' (Now is the time I would like to engage in a discussion with Japanese on an equal basis). Gekkan shakaitō 472: 110-15.

- 1986. 'Hokkaido o nihonkoku e utta oboe wa naiga' (I don't recall selling Hokkaido to the Japanese state). Asahi Journal 28, no. 45: 110.

- 1980. Ainu No Hi (Ainu's Memorial). Tokyo: Asahi shimbunsha.

Kikuchi, Isao 1994. Ainu minzoku to nihonjin (The Ainu nation and the Japanese). Tokyo: Asahi Shimbunsha.

Kimura, Hiroshi 2000. Distant Neighbors. 2 vols. Armonk, New York: M. E. Sharpe.

- 1980. Soren to Roshiajin (The Soviet Union and the Russians). Tokyo: Soyosha.

Kitahara, Ryuzō 1983. 'Gendai Ni Ikiru Ainu' (Ainu living today). Sekai 450, no. 5: 1.

Larson, Eric, Z. Johnson, and M. Murphy 2008. 'Emerging Indigenous Governance: Ainu Rights at the Intersection of Global Norms and Domestic Institutions'. Alternatives: Global, Local, Political 33, no. 1: 53-82.

Levin, Mark 2008. 'The Wajin's Whiteness: Law and Race Privilege in Japan' (unofficial English translation). Hōritsu Jihō 80, no. 2: 80-91.

- 1999, 'Kayano et al. v. Hokkaido Expropriation Committee: "The Nibutani Dam Decision"', International Legal Materials (394), 1-40. Accessed 10 October 2010 at http:/ / papers.ssrn.com/sol3/ papers.cfm?abstract_id=1635447.

Liebersohn, Harry 1994. 'Discovering Indigenous Nobility: Tocqueville, Chamisso, and Romantic Travel Writing'. The American Historical Review 99, no. 3: 746-66.

Matsui, Tsuneyuki 1972. 'Ainu ronkō' (Study of the Ainu). In K. Tanigawa (ed), Ainu, pp. 565-80. Tokyo: Shin jinbutsu ōraisha.

Morris-Suzuki, Tessa 1998. Re-Inventing Japan. London: M. E Sharpe.

- 2000. Henkyō kara nagameru: ainu ga keikensuru kindai (Observing from the periphery: modernity as experienced by Ainu).Tokyo: Misuzu shobō.

Narita, Tokuhei 1973. 'Ainu toshite no watashi no onnen' (My deep-seated grudge as an Ainu). Chūō Kōron 88, no. 8: 328-36.

- 1981. 'Ainu wa teki wo sagashiteinai' (Ainu were not looking for enemies). Asahi Journal 23, no. 27: 96-99.

Nishino, Ryota 2007. 'Making of the Empire from the Home Front or Internal Colonization?' Paper presented at Asian Studies Conference Japan. Tokyo, June 23.

Nomura, Gi'ichi 1993. 'Hoppōryōdo wa dare no mono?' (To whom do the Northern Territories belong?). In S. Ishii, Ainu no hon (The book of Ainu), pp 150-55. Tokyo: Takarajima sha.

Ogawa, Tokumei 1974. '"Horobi" no fuchi kara no sakebi' (A cry from the tip of the cliff). Asahi Journal 16, no. 1: 36-40. 
Oguma, Eiji 2007. 'The Postwar Intellectuals' View of Asia'. In J. Victor Koschmann and Sven Saaler (eds.), Pan-Asianism in Modern Japanese History, pp. 200-12. London: Routledge.

- 2002. A Genealogy of 'Japanese' Self-Images. Translated by David Askew. Edited by Yoshio Sugimoto, Japanese Society Series. Melbourne: Trans Pacific Press. Originally published in Japanese as Tan'itsu Minzoku Shin'wa No Kigen (The origins of the myth of a homogenous nation). Tokyo: Shinshōsha, 1995.

- 1998. '"Nihonjin" no kyōkai' (The boundaries of the Japanese). Tokyo: Shinyosha.

Sasamori, G. [1893] 1988. Chishima tanken (Expedition to Chishima). Meiji hoppō chōsa tankenki shūsei (Collection of Meiji era northward expedition chronicles). Tokyo, Yumata shobō.

Satō Kōji et al. 2009. 'Ainu seisaku no arikata ni kansuru yūshikisha kondankai no hōkokusho' (A report by the Expert Group on Ainu Policy). Tokyo: Cabinet Office. Accessed 15 September 2009 at http://www.kantei.go.jp/jp/singi/ainu/dai10/ siryou1.pdf.

Shiba, Ryotaro [1992] 1997. Ohotsuku Kaidō (The Ohotsk highway). Tokyo: Asahi shimbunsha.

Siddle, Richard 2002. 'An Epoch Making Event? The 1997 Ainu Cultural Promotion Act and Its Impact'. Japan Forum 14, no. 3: 405-23.

- 1996. Race, Resistance and the Ainu of Japan. London: Routledge.

Suzuki, Muneo 2008a. 'Wareware ainu giren ga mezashita mono' (What we, the members of the Group of Diet Members for Establishing the Rights of Ainu People, aimed for). Gekkan Nippon 12, no. 8: 48-55.

- 2008b. 'Shin no aikokusha to wa ikanaru mono ka' (What kind of person is a real patriot). Gekkan Nippon 12, no. 10: 64-71.

Suzuki, Shogo 2005. 'Japan's Socialization into Janus-Faced European International Society'. European Journal of International Relations 11, no. 1: 127-64.

Takahashi, Tomio 1982. 'Ainu shikan kakuritsu no tame no josho' (An introductory chapter towards establishment of Ainu view of history). Chūō Kōron 97, no. 13: 290-302.

Takakura, Shinichiro 1942. Hokuhen, Kaitaku, Ainu (Northern Frontier, Pioneering, Ainu). Tokyo: Takemura shobō.

- , and John A. Harrison 1960. 'The Ainu of Northern Japan'. Transactions of the American Philosophical Society 50, no. 4: 1-88.

Taoka, Ryōichi (ed) 1962. Hoppōryōdo no chii (The status of the Northern Territories). Tokyo, Nanpō dōhō engokai.

Tanaka, Stefan 1993. Japan's Orient. London: University of California Press.

Todorov, Tzvetan 1984. The Conquest of America: The Question of the Other. Translated by Richard Howard. New York: Harper \& Row.

Umehara, Takeshi [1982] 1985. 'Japanese Culture and Ainu Culture'. In Don Kenny (ed), Nihon Bunka O Saguru (Explorations in Japanese culture), pp. 6-19. Tokyo: Kodansha.

- 1984. 'Nihon kodai no metafijikku' (The metaphysics of ancient Japan). Gendai Shiso 12, no. 8: 30-51.

- 1982. 'Nihongo to ainugo wa igengo nanoka' (Are Japanese and Ainu languages really different). Chūō Kōron 97, 13: 254-74.

Yamamoto Kazuaki (ed) 1992. Ainu Moshiri: ainu minzoku kara mita ‘hoppōryōdo henkan' $k o ̄ s h o ̄$ (Ainu Moshir: 'Return of the Northern Territories' negotiations as seen from the Ainu nation). Tokyo: Ochanomizu shobō.

Yūki, Shōji 1997. Charanke (A Prolonged Discussion). Tokyo: Sōfūkan. 